\title{
Frond architecture of the rootless duckweed Wolffia globosa
}

\author{
Jingjing Yang ${ }^{1}$, Xuyao Zhao ${ }^{1}$, Gaojie Li ${ }^{1}$, Shiqi Hu, ${ }^{1,2}$ and Hongwei Hou ${ }^{1 *}$ (D)
}

\begin{abstract}
Background: The plant body in duckweed species has undergone reduction and simplification from the ancient Spirodela species towards more derived Wolffia species. Among the five duckweed genera, Wolffia members are rootless and represent the smallest and most reduced species. A better understanding of Wolffia frond architecture is necessary to fully explore duckweed evolution.

Results: We conducted a comprehensive study of the morphology and anatomy of Wolffia globosa, the only Wolffia species in China. We first used X-ray microtomography imaging to reveal the three-dimensional and internal structure of the $W$. globosa frond. This showed that new fronds rapidly budded from the hollow reproductive pocket of the mother fronds and that several generations at various developmental stages could coexist in a single W. globosa frond. Using light microscopy, we observed that the meristem area of the W. globosa frond was located at the base of the reproductive pocket and composed of undifferentiated cells that continued to produce new buds. A single epidermal layer surrounded the $W$. globosa frond, and the mesophyll cells varied from small and dense palisade-like parenchyma cells to large, vacuolated cells from the ventral to the dorsal part. Furthermore, $W$. globosa fronds contained all the same organelles as other angiosperms; the most prominent organelles were chloroplasts with abundant starch grains.

Conclusions: Our study revealed that the reproductive strategy of $W$. globosa plants enables the rapid accumulation of biomass and the wide distribution of this species in various habitats. The reduced body plan and size of Wolffia are consistent with our observation that relatively few cell types are present in these plants. We also propose that $W$. globosa plants are not only suitable for the study of structural reduction in higher plants, but also an ideal system to explore fundamental developmental processes of higher plants that cannot be addressed using other model plants.
\end{abstract}

Keywords: Wolffia globosa, Morphology, Three-dimensional structure, Light microscopy, Ultrastructure

\section{Background}

Duckweeds, aquatic monocotyledonous plants of the family Lemnaceae, include five genera (Spirodela, Landoltia, Lemna, Wolffiella, and Wolffia) with variable morphologies and living habits, propagating mostly by vegetative reproduction $[1,2]$. Duckweeds have attracted

\footnotetext{
* Correspondence: houhw@ihb.ac.cn

'The State Key Laboratory of Freshwater Ecology and Biotechnology, The Key Laboratory of Aquatic Biodiversity and Conservation of Chinese Academy of Sciences, Institute of Hydrobiology, Chinese Academy of Sciences, Wuhan 430072, China

Full list of author information is available at the end of the article
}

attentions for their economic value and potential to ameliorate resource limitations and environmental problems [3]. For example, duckweeds are widely used for standardized toxicity testing of various water contaminants including nitrogen, phosphorus, metals, and numerous organic compounds $[4,5]$. Duckweeds also possess good qualitative and quantitative nutritional profiles without detectable anti-proliferative or cytotoxic effects and could serve as a new source of human food [6]. Duckweed-based expression systems with strictly controlled formats have been developed to produce various recombinant proteins with relatively high yield $[7,8]$.

(c) The Author(s). 2021 Open Access This article is licensed under a Creative Commons Attribution 4.0 International License, which permits use, sharing, adaptation, distribution and reproduction in any medium or format, as long as you give appropriate credit to the original author(s) and the source, provide a link to the Creative Commons licence, and indicate if changes were made. The images or other third party material in this article are included in the article's Creative Commons licence, unless indicated otherwise in a credit line to the material. If material is not included in the article's Creative Commons licence and your intended use is not permitted by statutory regulation or exceeds the permitted use, you will need to obtain permission directly from the copyright holder. To view a copy of this licence, visit http://creativecommons.org/licenses/by/4.0/. The Creative Commons Public Domain Dedication waiver (http://creativecommons.org/publicdomain/zero/1.0/) applies to the data made available in this article, unless otherwise stated in a credit line to the data. 
Duckweeds also may be valuable feedstock for biofuel production due to their high biomass and starch accumulation $[9,10]$. Furthermore, their rapid growth rate, ease of cultivation and transformation, direct contact with water, and ability to adapt to environmental changes make duckweeds suitable plant models and excellent materials for physiological studies [3].

Duckweeds have undergone reduction and simplification of the plant body from the ancient Spirodela species towards the more-derived Wolffia species [11]. Among the five duckweed genera, Wolffia members are rootless and represent the smallest $(0.5-1 \mathrm{~mm})$ and mostreduced species; other duckweed species (including Spirodela, Landoltia, and Lemna) produce adventitious roots. DNA content estimates also vary nearly thirteenfold among duckweed species, ranging from $158 \mathrm{Mbp}$ in Spirodela polyrhiza to $1881 \mathrm{Mbp}$ in Wolffia arrhiza [12], and negatively correlate with body size [12-14]. The striking variation in body plan and size among duckweeds is one of the most extreme examples of structural reduction in any family. However, we lack knowledge about the mechanisms driving its occurrence within the plant kingdom.

Two studies by Landolt [11] described the morphology of the Wolffia genus and characterized its members based on their frond shape, frond width, number of stomata, stigma with or without pigment cells, etc. Anderson et al. [15] first reported the light and electron microscopic structure of the W. arrhiza frond, revealing that $W$. arrhiza fronds varied considerably from mature chlorenchymous tissue to the meristematic area where numerous daughter fronds develop. The frond structure of Wolffia australiana was similar to that of W. arrhiza; however, the $W$. australiana chloroplasts were concentrated in dorsal mesophyll cells [16]. White and Wise [17] revealed the differences in mesophyll anatomies between Wolffia columbiana and Wolffia borealis: the chloroplasts were located mainly in the epidermis of $W$. columbiana with a single mesophyll cell size and type, but were concentrated in the dorsal part of W. borealis with a steep gradient in cell size, as in $W$. australiana and $W$. arrhiza. Lemon and Posluszny [18] were the first to compare the developmental morphology of shoots in S. polyrhiza, Lemna minor, and W. borealis, which revealed the successive formation of new generations in these three duckweed species and their progressive simplification from Spirodela to Lemna to Wolffia. Sree et al. [19] reported the unique morphology of vegetative and generative propagation in Wolffia microscopica using light and electron microscopy. They observed flowering in different generations of W. microscopica at the same time [19]. Furthermore, W. microscopica fronds often possessed a ventral projection and a special 'pseudoroot' structure, in contrast to other duckweed species, which lack pseudoroots [19]. These previous studies demonstrated that members of the Wolffia genus vary distinctively in morphology, anatomy, growth etc. in adaption to different living environments.

Wolffia globosa is the only Wolffia species in China [20] and it has a genome size of $1300 \mathrm{Mbp}$ [12]. Stable and transient transformation methods for W. globosa have been established [21]. Based on this efficient genetic transformation system, W. globosa has been used to express a protective edible vaccine antigen against fish vibriosis with high survival of vaccinated fish (63.3\%), which indicated that W. globosa could serve as a bioreactor to produce edible vaccines [7]. W. globosa is also a good indicator of metal pollution in aquatic environments [22, 23]. Early studies by Landolt [11] reported the morphology of W. globosa. Huang [20] studied the phylogeny and genetic diversity of W. globosa in China based on sequencing of the mat-K gene and random amplified polymorphic DNA (RAPD) markers. Huang [20] also preliminaily compared the anatomy of the turion, frond, and flowering structures among W. globosa individuals from the field. The morphology and anatomy of W. globosa still need further investigation to reveal its unique characteristics that may be of importance in basic and applied research. Here, we report a comprehensive study of the morphology and anatomy of W. globosa. The findings provide a foundation for future research on duckweed growth, development, physiology, and evolution. Biological research on duckweeds is growing as genomes of some duckweed species have been sequenced [24]. We hope to attract more investigators and investors to join our efforts and realize the great potential of duckweed as a model system for basic and applied research in plants.

\section{Results}

\section{Morphology of the W. globosa frond}

The three-dimensional (3D) volumes of the W. globosa frond are shown in Fig. 1 and Movie S1. The ovalshaped W. globosa frond could be divided into dorsal, ventral, and lateral parts (Fig. 1A1). There was one big cavity in both the mother frond (MF) and daughter frond (DF1) named the reproductive pocket (RpM and RpD, respectively) (Fig. 1A2-A5). The MF had two visible daughter fronds (DF1 and DF2), one (DF2) budding from the base of the RpM. The DF1 also had two new buds (GF1 and GF2) (Fig. 1A3-A5). The empty RpM with the new bud (DF2) was exposed when the attached daughter frond (DF1) was separated (Fig. 1B2-B5). It was located at one end of the MF and opened when DF1 protruded from the MF. Stomata were found only in the dorsal part of the frond; no stoma were found in the ventral and lateral parts (Fig. $1 \mathrm{~A} 1-\mathrm{A} 2, \mathrm{~B} 1-\mathrm{B} 2)$. We further observed the structure of the $\mathrm{X}-\mathrm{Y}, \mathrm{X}-\mathrm{Z}$, and $\mathrm{Z}-\mathrm{Y}$ 


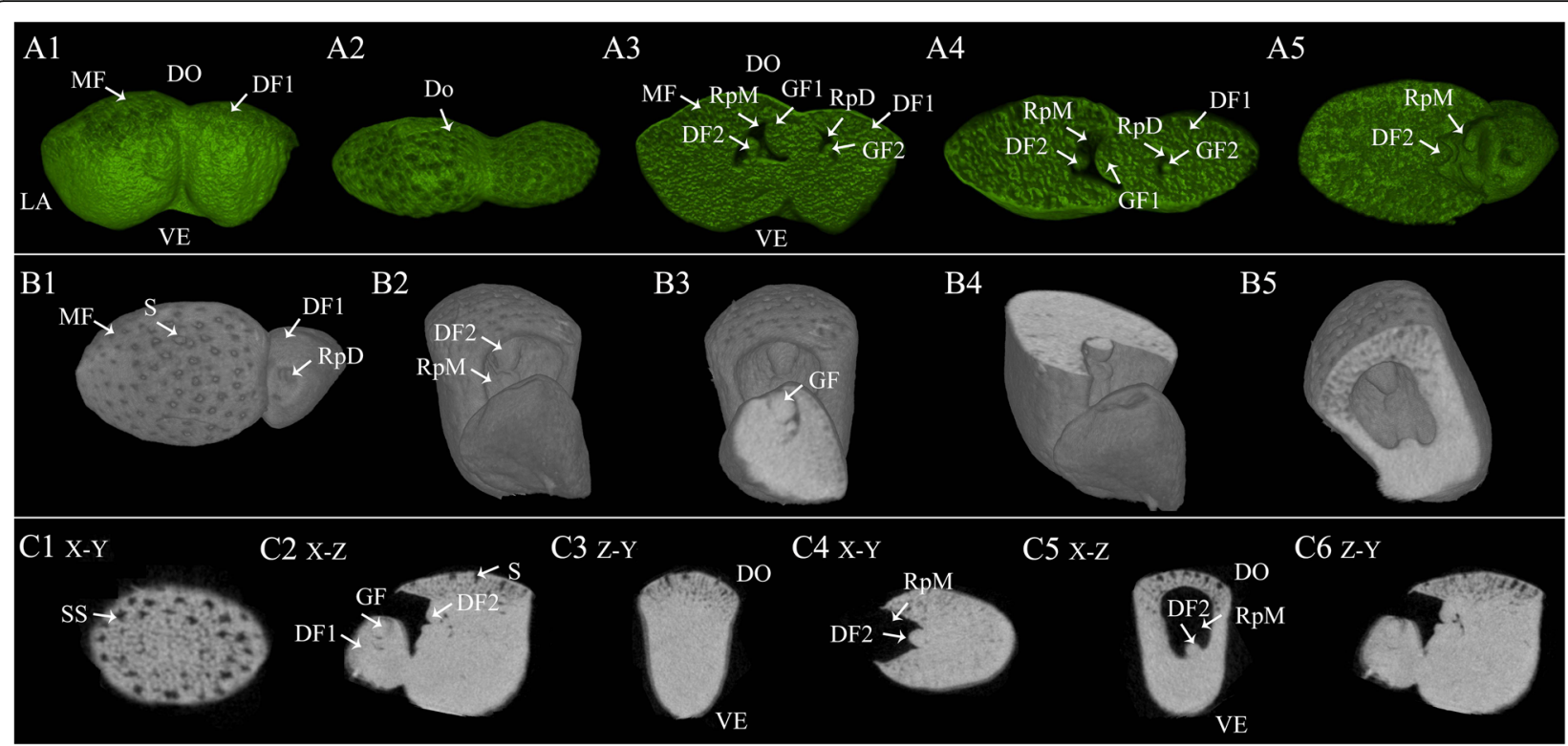

Fig. 1 The three-dimensional volumes of W. globosa fronds showing the mother frond with daughter fronds. DO- dorsal part, VE- ventral part, LA- lateral part, MF- mother frond, RpM- reproductive pocket of MF, RpD- reproductive pocket of the daughter frond, DF1- the first daughter frond of MF, DF2- the second daughter frond of MF, GF1- the first daughter frond of DF1, GF2- the second daughter frond of DF1-, S- stoma, SSsubstomatal cavity. Bar $=50 \mu \mathrm{m}$

axes at two points on the dorsal part (Fig. 1 C1-C5). Stomata and substomatal cavities were clearly observed on the dorsal side (Fig. 1 C1-C3). The RpM was one empty pouch where new generations budded (Fig. 1 C4C5).

We also observed the morphology of the W. globosa frond by scanning electron microscopy (SEM). We found that the stomata were densely distributed on the dorsal surface with densities of $314.34 \pm 46.99 / \mathrm{mm}^{2}$ (Fig. 2 B). The guard cells, accessory guard cells, and epidermal cells made the entire stoma form an unusual flower-ring structure while the cells on the ventral and lateral parts were pentagonal (Fig. 2 C-D). The DF was released from the RpM and connected with its MF by a stalk structure (Fig. 2 E-F). The broken stalk connecting the MF and DF remained in the RpM when the DF was released. The structure of the stalk was similar to the vascular tissue of plants and filled with cavities. The other end of the stalk structure was located near the $\mathrm{RpD}$ and the detachment left a visible scar when the DF was released. The scar was similar in structure to the abscission layer (Fig. $2 \mathrm{H}-\mathrm{I}$ ).

\section{Light microscopy observation}

Horizontal and vertical cross-sections of W. globosa are shown in Fig. 3. We confirmed previous results that the developing DFs were produced from the meristematic area in the base of the RpM (Fig. $3 \mathrm{~A}-\mathrm{C}$ ). This meristematic area was composed of some undifferentiated cells that continued to multiply, producing new DFs.
The RpM became larger with the growth of DFs and opened when they were released (Fig. $3 \mathrm{G}$ ). Most chloroplasts were concentrated in the dorsal part (Fig. $3 \mathrm{D}$ ). The stomata were only found in the upper epidermis (dorsal side), and prominent substomatal cavities could be observed distinctly from the vertical cross-section. From the dorsal to ventral side, the mesophyll cells varied in size and changed from small and dense palisadelike parenchyma cells to large and empty vacuolated cells with many intercellular air spaces. Furthermore, the chloroplasts showed a developmental gradient from the youngest to the oldest fronds. Compared with the MF, DFs were at an earlier differentiation stage and mainly consisted of many dividing cells with larger nuclei (Fig. 3 E). The outermost layer of the MF was composed of a single layer of epidermal cells containing annular distributed chloroplasts (Fig. 3 F).

\section{Ultrastructure of the W. globosa frond}

The W. globosa frond contains the same organelles as other angiosperm plants (Fig. 4). The most prominent organelles were chloroplasts, which were mainly distributed in the mesophyll cells of the upper epidermis (Fig. 4 A). There were no significant differences in the size and elaboration of the thylakoid system among chloroplasts. The photosynthetic membrane system of these lens-shaped chloroplasts was well developed, and the individual grana were composed of three to eight thylakoids (Fig. 4 B-C). Starch grains occurred in the chloroplasts of almost all the palisade-like parenchyma 


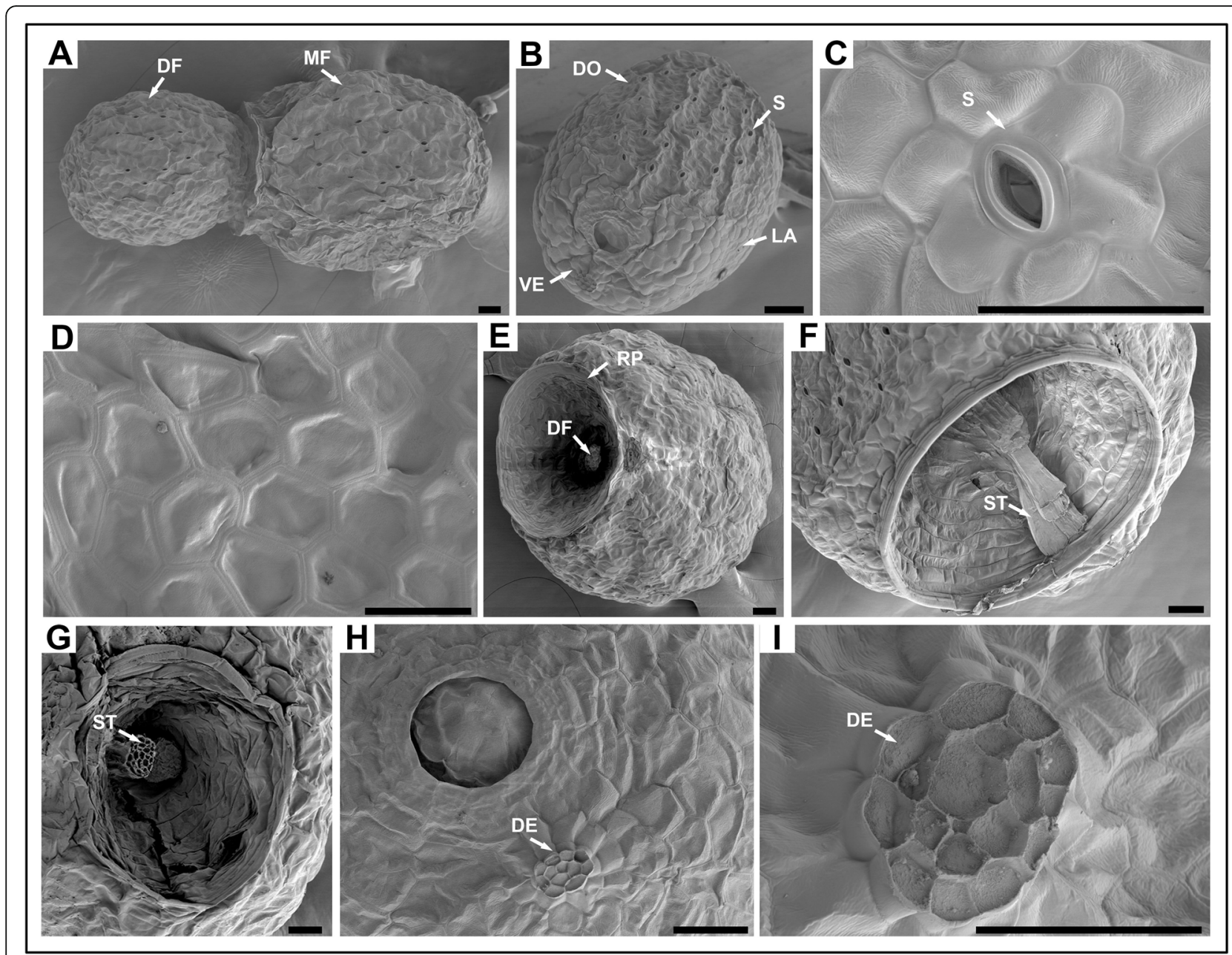

Fig. 2 Scanning electron micrographs of W. globosa fronds. A, A single frond composed of mother frond (MF) and daughter frond (DF). B, The frond was divided into dorsal (DO), ventral (VE) and lateral (LA) parts. C-D, Stomata (S) and epidermal cells on the dorsal part. E-G, The daughter frond produced from reproductive pocket (RP) and connected with the mother frond by the stalk structure (ST). $\mathbf{H}-\mathbf{I}$, The detachment (DE) of the ST and its magnification. Bars $=50 \mu \mathrm{m}$

cells but were more abundant in the chloroplasts of mature mesophyll cells than in the meristematic area or the developing DFs (Fig. 4 D-E). There were also more mitochondria in the meristematic area of the MF than in that of the DFs, which had larger nuclei and smaller vacuoles (Fig. 4 F-G). Microbodies were often, but not always, found in close association with the chloroplasts. Other organelles such as Golgi, free ribosomes, and rough endoplasmic reticulum were not so prominent. The outermost cells of the RpM were mostly vacuolated and organelles were almost invisible (Fig. $4 \mathrm{H}$ ). Furthermore, we found elaborate cell wall projections, which were classified as transfer cells, in most adjacent mature mesophyll cells. These transfer cells were ingrowths, increasing the area of the cell membrane (Fig. 4 I).

\section{Discussion}

To complete their life, most plant species require all the vegetative (shoot, stem, and root) and reproductive (flower, fruit, and seed) organs. These plants produce numerous branches through the growth of the shoot apical meristem (SAM) and root apical meristem (RAM) [25]. However, the morphology of Wolffia fronds does not fit traditional botanical descriptions. The W. globosa frond normally budded new fronds from its unique meristematic area by vegetative propagation. The meristematic area of the W. globosa frond was located at the base of the RpM and was a collection of undifferentiated cells with the ability to divide; there were no morphologically strict divisions in the meristem area. Our finding of frond propagation in W. globosa is consistent with previous studies on W. arrhiza [15], W. australiana [16], W. microscopica [19], W. columbiana, and W. borealis 


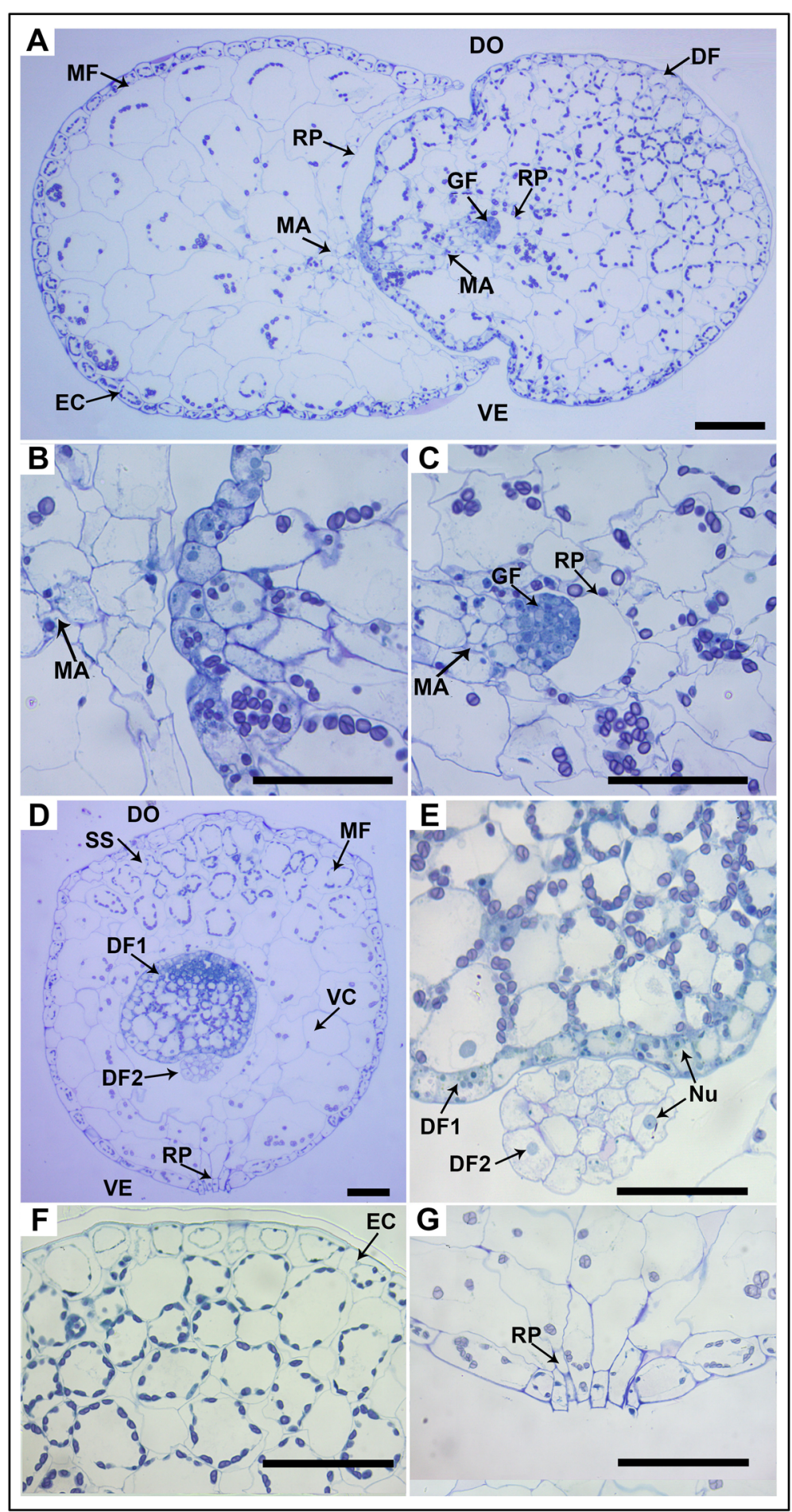

Fig. 3 Microscopic observations of W. globosa fronds. A-C, Light micrograph of vertical cross-sections of a W. globosa frond showing the daughter fronds (DF, GF) were budding from the meristematic area (MA) in reproductive pocket (RP) of the mother frond (MF). DO- dorsal part, VE- ventral part. D, Light micrograph of horizontal cross-section of a W. globosa frond showing MF and daughter fronds (DF1, DF2), vacuolated cells (VC) and substomatal cavity (SS). E-G, Magnification of DF1 and DF2 with larger nuclei (NU), epidermal cells (EC) and RP. Bars $=200 \mu m$ 


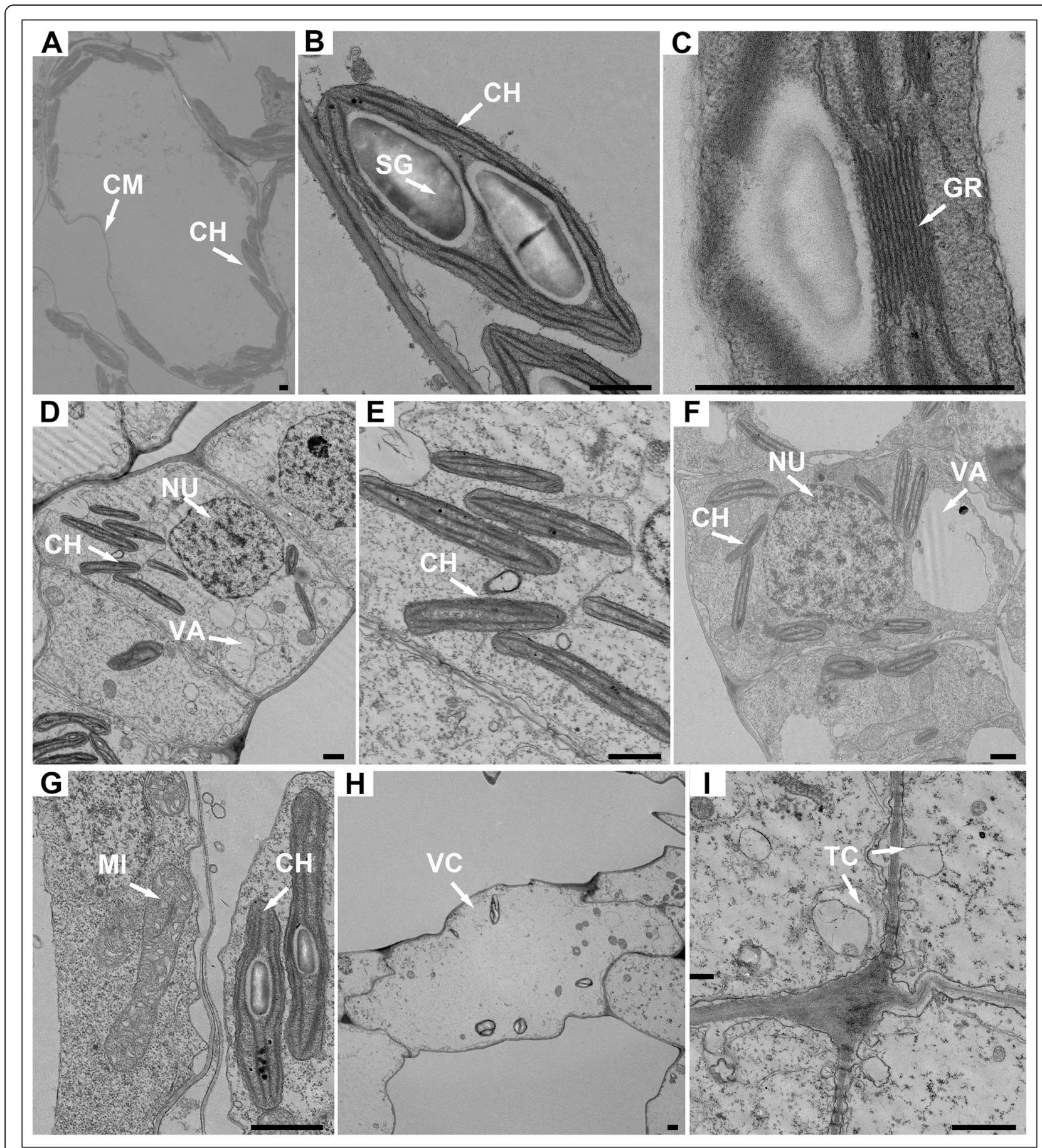

Fig. 4 Transmission electron micrographs of W. globosa fronds. A-B, Lens-shaped chloroplasts (CH) containing starch grains (SG) distributed in mature mesophyll cells and their magnification, $\mathrm{CM}$ - cell membrane. C, The photosynthetic membrane system of $\mathrm{CH}$ containing a granum (GR) composed of thylakoids. D, Cell of meristematic area showing larger nuclei (NU) and smaller vacuoles (VA). E, The CH in meristematic area. F-G, Cell of daughter frond showing more mitochondria (MI). H, Cell of reproductive pocket was highly vacuolated (VC, vacuolated cells). I, Transfer cells (TC) in most adjacent mature mesophyll cell. Bars $=1 \mu \mathrm{m}$

$[17,18]$. We speculated that the dividing cells may perform different functions than the SAM in A. thaliana including expression of some key genes involved in SAM activity and the distribution of auxin and cytokinin. This latter possibility could be investigated using reporter genes based on the established genetic transformation system for W. arrhiza and W. globosa $[26,27]$. 
The new generations produced by vegetative propagation were called DFs or new buds (as in a budding yeast) and were released horizontally from the RpM. Usually, several individuals at different developmental stages coexisted in a single $W$. globosa frond. A single W. australiana frond produces $11 \mathrm{DFs}$ on average and lives for about 17 days on average [16]. Each bud begins to senesce on the 10th day of survival [16]. Our study also confirmed the rapid propagation of W. globosa from the structural perspective. This reproductive strategy enabled rapid accumulation of biomass in Wolffia, which roughly doubled in $48 \mathrm{~h}$, and allows its wide distribution in various habitats around the world [28]. The budding reproduction of Wolffia was clearly observed in our study by X-ray microtomography for the first time. Wolffia seldom flower under natural conditions, and no seed has been reported so far. However, Wolffia flowers have been reported in the laboratory $[29,30]$; the causes of its reduction of sexual reproduction could be revealed in the future.

Our work and previous studies identified some differences in anatomical structure among different Wolffia species (Table 1). The most important was that the mesophyll cells of $W$. arrhiza, W. borealis, W. australiana and W. globosa showed a steep gradient in cell size from dorsum to ventrum with chloroplasts concentrated in the dorsal part, while W. columbiana had only a single mesophyll cell size and type with many fewer epidermal chloroplasts. Therefore, W. columbiana fronds would have a lower photosynthetic capacity compared with the other four Wolffia species [17]. From Spirodela to Wolffia, the size of fronds has changed; and the roots have been reduced, causing a reduction in the number of different cell types in Wolffia plants, which consist only of epidermis cells, mesophyll cells and some highly vacuolated cells. In contrast, Spirodela and Lemna plants have more cell types, especially vascular tissue [18]. The reduced body plan and size of Wolffia might be the reason for the presence of relatively few cell types in these plants. The evolution of Wolffia plants with higher specific surface area and individual flexibility also enabled them to acclimate well to changing environments. The morphology and structure of W. microscopica are also quite different from the above five Wolffia species. W. microscopica has a flattened frond and a presence pseudoroot, which did not exist in any other member of Wolffia [19]. These observations indicated that W. microscopica might be more closely related to duckweeds of other genera (Spirodela, Lemna, Landoltia) and thus link Wolffia and other duckweed plants [19]. Therefore, W. microscopica might be a key species in which to explore the basis of the observed root reduction in duckweeds.

Table 1 The anatomical structure of six Wolffia species

\begin{tabular}{|c|c|c|c|c|c|c|}
\hline & $\begin{array}{l}\text { Wolffia } \\
\text { arrhiza }\end{array}$ & $\begin{array}{l}\text { Wolffia } \\
\text { columbiana }\end{array}$ & $\begin{array}{l}\text { Wolffia } \\
\text { borealis }\end{array}$ & Wolffia australiana & Wolffia globosa & Wolffia microscopia \\
\hline Epidermis & $\begin{array}{l}\text { A single } \\
\text { epidermal } \\
\text { layer with } \\
\text { chloroplasts }\end{array}$ & $\begin{array}{l}\text { A single } \\
\text { epidermal } \\
\text { layer with } \\
\text { chloroplasts }\end{array}$ & $\begin{array}{l}\text { A single } \\
\text { epidermal layer } \\
\text { with } \\
\text { chloroplasts }\end{array}$ & $\begin{array}{l}\text { A single epidermal layer } \\
\text { with chloroplasts }\end{array}$ & $\begin{array}{l}\text { A single epidermal layer } \\
\text { with chloroplasts }\end{array}$ & $\begin{array}{l}\text { The upper single epidermis } \\
\text { almost completely lacks } \\
\text { chloroplasts }\end{array}$ \\
\hline Stomata & - & - & $40-50$ & More than 40 & $314.34 \pm 46.99 / \mathrm{mm}^{2}$ & $\begin{array}{l}\text { Two to three rows of } \\
\text { stomata in the dorsal } \\
\text { surface }\end{array}$ \\
\hline Mesophyll & $\begin{array}{l}\text { The upper } \\
\text { palisade-like } \\
\text { cells sub- } \\
\text { jacent to the } \\
\text { lower vacuo- } \\
\text { lated cells }\end{array}$ & $\begin{array}{l}\text { A single } \\
\text { mesophyll } \\
\text { cell size and } \\
\text { type }\end{array}$ & $\begin{array}{l}\text { Vary in size } \\
\text { from small cells } \\
\text { toward the } \\
\text { dorsum to large } \\
\text { cells toward } \\
\text { ventrum }\end{array}$ & $\begin{array}{l}\text { The upper third was loosely } \\
\text { packed palisade-like paren- } \\
\text { chyma cells, the lower two } \\
\text { thirds were composed of } \\
\text { large, highly vacuolated } \\
\text { cells }\end{array}$ & $\begin{array}{l}\text { Vary in size from small } \\
\text { and dense palisade-like } \\
\text { parenchyma cells in dor- } \\
\text { sum to large and empty } \\
\text { vacuolated cells in } \\
\text { ventrum }\end{array}$ & $\begin{array}{l}\text { Centre composed of loosely } \\
\text { arranged parenchymatic } \\
\text { cells interspersed with air } \\
\text { spaces towards the dorsal } \\
\text { side and more tightly } \\
\text { packed parenchymatous } \\
\text { cells with small air spaces } \\
\text { towards the ventral surface }\end{array}$ \\
\hline Chloroplasts & $\begin{array}{l}\text { Concentrated } \\
\text { in epidermis, } \\
\text { mesophyll } \\
\text { cells and } \\
\text { vaculated } \\
\text { cells }\end{array}$ & $\begin{array}{l}\text { Mainly } \\
\text { concentrated } \\
\text { in epidermis }\end{array}$ & $\begin{array}{l}\text { Concentrated in } \\
\text { dorsal } \\
\text { mesophyll cells }\end{array}$ & $\begin{array}{l}\text { Concentrated in dorsal } \\
\text { mesophyll cells }\end{array}$ & $\begin{array}{l}\text { Both in the mesophyll } \\
\text { cells and epidermis }\end{array}$ & $\begin{array}{l}\text { Prominent in the lower } \\
\text { epidermis and ventral } \\
\text { parenchymatic cell layers }\end{array}$ \\
\hline $\begin{array}{l}\text { Transfer } \\
\text { cells }\end{array}$ & - & $\begin{array}{l}\text { Present in the } \\
\text { epidermis }\end{array}$ & Absent & - & $\begin{array}{l}\text { Present in adjacent } \\
\text { mature mesophyll cell }\end{array}$ & - \\
\hline Pseudoroot & Absent & Absent & Absent & Absent & Absent & Present \\
\hline Reference & {$[15]$} & [17] & $\begin{array}{l}{[17] ;} \\
{[18]}\end{array}$ & {$[16]$} & Current study & [19] \\
\hline
\end{tabular}


The reduction of the root in Wolffia is one of the most striking examples of structural reduction in the plant kingdom. Duckweeds include five genera; members of Wolffia and Wolffiella are rootless, and members of Spirodela, Landoltia, and Lemna produce either a single or few roots [31]. There is a reduction of the number of roots from Spirodela to Lemna and they disappear entirely in Wolffia. Early studies suggested that duckweeds did not use their roots to acquire nutrients, and instead acquire nutrients through their fronds [32-35]. Echlin et al. [36] found that most absorption of ions occurred in the root tip region of $L$. minor, and observed a Casparian band structure in the endodermis of the root tip. They suggested that the root of $L$. minor can not only absorb nutrients and water but also transport these to the frond. Kim [37] carried out a detailed study of root development of $S$. polyrhiza and found a large number of plasmodesmata between the cells of the root. They therefore concluded that the transport of metabolites between the root and frond may rely on the symplastic pathway. Cedergreen and Madsen (2003) reported that both the root and fronds of $L$. minor had the ability to absorb $\mathrm{NO}_{3}{ }^{-}$and this ability was affected by light irradiance. The root of Fand stabilize the plant on the water surface. However, White and Wise [17] suggested the rootless Wolffia stay afloat and upright not by buoyancy but by surface tension. In their opinion, if buoyancy kept Wolffia plants at the water's surface, then they would sink late in the day as their starch content reached a maximum. In our study, the dorsal part of W. globosa was always above the water, and it was difficult to submerge the plants or turn them over. In addition, most of the chloroplasts, which were filled with starch grains, were concentrated at the dorsal side. Previous studies have shown that dormant individuals of Wolffia were full of starch grains and sank in the water [20]. We speculate that the content of starch grains affects the stable floating of Wolffia. Furthermore, the loss of the nutrient uptake and stabilization functions of the root in Wolffia may have allowed them to lose this organ. Phylogenetic analysis using different molecular markers has confirmed that duckweeds comprise a single monophyletic clade [38], suggesting that rootlessness has a single evolutionary origin in Lemnoideae.

We propose that Wolffia is a suitable model to study structural reduction in angiosperms and to explore the cause of rootlessness. First, Wolffia is easy to cultivate, completes its life cycle in the lab, and reproduces quickly. Second, Wolffia plants can be genetically transformed, as can the rooted Spirodela and Lemna, allowing us to conduct genetic studies [21, 39, 40]. Wolffia species are the smallest flowering plants in the world, in both size and morphological structures, containing one leaf, one stamen and one gynoecium, which represent the core elements for angiosperms to complete their life cycle. Hillman [41] pointed out that although the gross morphology and vegetative reproduction of Lemnaceae are somewhat unusual, their anatomy, particularly the prominent air spaces and reduced vascular structures, resembles that of many aquatic angiosperms. Anderson et al. [15] also pointed out that although Wolffia lacks vascular tissue, the range of tissue and cell types appears as heterogeneous as in most leaves and varies considerably from meristematic to mature chlorenchymous tissue. Not only is it suitable to study structural reduction, but Wolffia would also be an ideal system to explore fundamental processes of angiosperm development that cannot be addressed using other model plants.

\section{Conclusions}

This first comprehensive study of the morphology and anatomy of $W$. globosa. Revealed that the morphology of W. globosa did not fit the traditional botanical descriptions. The rootless W. globosa budded new fronds from the unique meristematic area by vegetative propagation, and usually several generations coexisted in a single frond, as observed in other Wolffia species. This reproductive strategy enabled rapid accumulation of biomass and their wide distribution in various habitats around the world. The reduced body plan and size of Wolffia might be the reason for the presence of relatively few cell types in these plants. We also propose that Wolffia plants are not only suitable for the study of structural reduction in higher plants, but also an ideal system to explore the fundamental developmental processes of higher plants that cannot be addressed using other model plants.

\section{Methods}

\section{Plants cultivation and identification}

W. globosa (5563) plants were collected from East Lake $\left(\mathrm{N} 30^{\circ} 32^{\prime}, \mathrm{E} 114^{\circ} 21^{\prime}\right)$ at the city of Wuhan, Hubei Province, China (no permission was required to collect such plant samples). Plants were sterilized in $0.1 \%$ mercuric chloride for 2-3 min and then cultured in half-strength (1/2) Schenk \& Hildebrandt (SH) medium [42] at pH 5.5 containing $1 \%(\mathrm{w} / \mathrm{v})$ sucrose and $0.8 \%(\mathrm{w} / \mathrm{v})$ agar. Regenerated fronds of W. globosa were transferred to liquid 1/ $2 \mathrm{SH}$ medium for longer preservation. Cultivation was conducted at $25 \pm 1{ }^{\circ} \mathrm{C}$ under white light of $85 \mu \mathrm{mol} \mathrm{m}{ }^{-2}$ $\mathrm{s}^{-1}$ and 16-h day/8-h night photoperiod. W. globosa fronds in good condition were selected for experiments.

The identification of W. globosa (5563) was conducted by Jingjing Yang and P.P.M. Heenatigala using atpFatp $H$ barcode primers $[21,43]$. The identification results were submitted to the Rutgers Duckweed Stock Cooperative at the State University of New Jersey (http:// www.ruduckweed.org/register.html). W. globosa (5563) 
plants were preserved at the National Aquatic Biological Resource Center.

\section{D structure observation of W. globosa frond by X-ray microtomography (MicroCT) imaging}

We first used MicroCT to explore the morphology and internal structure of the $W$. globosa frond. The fronds were scanned at the MicroCT facility (Skyscan1267, Burker) and scans were obtained at a spatial resolution of $3 \mu \mathrm{m}(4032 \times$ 2688 pixel field of view), with an electron acceleration energy of $85 \mathrm{kV}$ and a current of $100 \mu \mathrm{A}$. Detector exposure time was $750 \mathrm{~ms}$, collecting 412 projections in "step and shoot" mode with no averaging, resulting in a scan duration of 9 min per sample. Radiograph reconstruction was carried out using NRecon reconstruction software (version 1.7.4.2, Bruker) with a beam hardening correction of 15 . Finally, the scanned area beyond the plant sample was removed and reconstructed into $3 \mathrm{D}$ volumes using a filtered backprojection algorithm.

\section{Light and electron microscope observation}

For SEM, the fresh fronds were fixed in $2.5 \%$ glutaraldehyde in phosphate-buffered saline (PBS) buffer $(1 \mathrm{M}, \mathrm{pH}$ 7.4) overnight at $4{ }^{\circ} \mathrm{C}$ followed by a stepwise ethanol and tert butanol dehydration. Then samples were dried using a freeze dryer (Hitachi ES-2030). The obtained specimens were examined with a scanning electron microscope (Hitachi S4800) at $30 \mathrm{kV}$.

For light and transmission electron microscopy (TEM), the samples were washed in PBS buffer after fixing overnight at $4{ }^{\circ} \mathrm{C}$. Then samples were post-fixed with $1 \% \mathrm{OsO}_{4}$ in PBS for $2 \mathrm{~h}$ at $4{ }^{\circ} \mathrm{C}$ following stepwise ethanol and acetone dehydration and infiltration with Spurr's epoxy resin. The treated samples were embedded and polymerized in Spurr's epoxy resin at $60{ }^{\circ} \mathrm{C}$ for $48 \mathrm{~h}$. Sections for light microscopy were cut using a LEICA EM UC 7 instrument with a glass knife and stained with $1 \%$ toluidine blue. The obtained specimens were photographed with an OLYMPUS BX53 camera. Ultra-thin sections $(70 \mathrm{~nm})$ for TEM were also cut using a LEICA EM UC 7 instrument and double-stained with $2 \%$ uranyl acetate and Sato's lead citrate. The obtained specimens were examined with a transmission electron microscope (Hitachi-7700) at $120 \mathrm{kV}$.

\section{Abbreviations}

3D: Three-dimensional; MicroCT: X-ray microtomography; PBS: Phosphatebuffered saline: RAM: Root apical meristem; SAM: Shoot apical meristem; SEM: Scanning electron microscopy; TEM: Transmission electron microscopy

\section{Supplementary Information}

The online version contains supplementary material available at https://doi. org/10.1186/s12870-021-03165-5

Additional file 1: Movis S1. The three-dimensional volumes of W. globosa frond.
Additional file 2: The raw data of Fig. 1

Additional file 3: The raw data of Fig. 2

Additional file 4: The raw data of Fig. $\mathbf{3}$

Additional file 5: The raw data of Fig. 4

\section{Acknowledgments}

We thank Xin Wang at The Analysis and Testing Center of Institute of Hydrobiology, Chinese Academy of Sciences for MicroCT experimental support.

\section{Authors' contributions}

$J Y$ and $X Z$ performed experiments and wrote the initial draft. GL and SH designed the figures and contributed to the editing of this article. $\mathrm{HH}$ planned and designed the research. All authors have read and approved the manuscript.

\section{Funding}

This work was supported by the National Natural Science Foundation of China [grant number 32001107] to JY, National Key R \& D Program [grant number 2020YFD0900305] to JY, Hubei Province Postdoctoral Science Foundation to JY, National Natural Science Foundation of China [Grant number31870384] to HH, National Key R \& D Program [grant number 2018YFD0900801, 2017YFE0128800] to HH, and International Partnership Program of Chinese Academy of Sciences [152342KYSB20200021] to HH. The funding organizations provided financial support to the research projects but were not involved in study design, data collection, data analysis, or writing of the manuscript.

\section{Availability of data and materials}

All data generated or analyzed during this study are included in this article (and its supplementary files) or available from the corresponding author on reasonable request. Plant materials are available from the corresponding author.

\section{Declarations}

Ethics approval and consent to participate

Not applicable.

Consent for publication

Not applicable.

\section{Competing interests}

The authors declare that they have no competing interests.

\section{Author details}

${ }^{1}$ The State Key Laboratory of Freshwater Ecology and Biotechnology, The Key Laboratory of Aquatic Biodiversity and Conservation of Chinese Academy of Sciences, Institute of Hydrobiology, Chinese Academy of Sciences, Wuhan 430072, China. ${ }^{2}$ Zhejiang Marine Development Research Institute, Zhoushan 316021, China.

Received: 24 November 2020 Accepted: 10 August 2021 Published online: 20 August 2021

\section{References}

1. Appenroth KJ, Borisjuk N, Lam E. Telling duckweed apart: genotyping technologies for the Lemnaceae. Chin J Appl Environ Biol. 2013;19:1-10

2. Les DH, Crawford DJ, Landolt E, Landolt E, Gabel JD, Kimball RT. Phylogeny and systematics of Lemnaceae, the duckweed family. Syst Bot. 2002;27:22140.

3. Appenroth KJ, Crawford DJ, Les DH. After the genome sequencing of duckweed-how to proceed with research on the fastest growing angiosperm? Plant Biol. 2015;17:1-4.

4. Yang JJ, Li GJ, Bishopp A, Heenatigala PPM, Hu S, Chen Y, et al. A comparison of growth on mercuric chloride for three Lemnaceae species reveals differences in growth dynamics that effect their suitability for use in either monitoring or remediating ecosystems contaminated with mercury. Front Chem. 2018a;6:112. https://doi.org/10.3389/fchem.2018.00112. 
5. Ziegler P, Sree KS, Appenroth KJ. Duckweed biomarkers for identifying toxic water contaminants? Environ Sci Pol. 2019;26:14797-822.

6. Sree KS, Dahsem HM, Chandran JN, Schneider B, Jahreis G, Appenroth KJ. Duckweed for human nutrition: no cytotoxic and no anti-proliferative effects on human cell lines. Plant Foods Hum Nutr. 2019;74(2):223-4. https://doi.org/10.1007/s11130-019-00725-X.

7. Heenatigala PPM, Sun ZL, Yang JJ, Zhao XY, Hou HW. Expression of LamB vaccine antigen in Wolffia globosa (duckweed) against fish vibriosis. Front Immunol. 2020;11:1857. https://doi.org/10.3389/fimmu.2020.01857.

8. Khvatkov P, Firsov A, Shvedova A, Shaloiko L, Kozlov O, Chernobrovkina M, et al. Development of Wolffia arrhiza as a producer for recombinant human granulocyte colony-stimulating factor. Front Chem. 2018;6:304. https://doi. org/10.3389/fchem.2018.00304

9. Liu $Y$, Chen $X Y$, Wang $X H$, Fang $Y$, Huang M, Guo L, et al. Improving biomass and starch accumulation of bioenergy crop duckweed (Landoltia punctata) by abscisic acid application. Sci Rep. 2018;8(1):9544. https://doi. org/10.1038/s41598-018-27944-7.

10. Sun Z, Guo W, Yang J, Zhao X, Chen Y, Yao L, et al. Enhanced biomass production and pollutant removal by duckweed in mixotrophic conditions. Bioresour Technol. 2020;317:24029.

11. Landolt $\mathrm{E}$. The family of Lemnaceae- a monographic study. In: Biosystematic investigations in the family of duckweeds (Lemnaceae), vol. 1. Zurich: Veroffentlichungen des Geobotanischen. Institutes der Eigd; 1986. p. 1-563.

12. Wang W, Kerstetter RA, Michael TP. Evolution of genome size in duckweeds (Lemnaceae). J Bot. 2011;2011:1-9. https://doi.org/10.1155/2011/570319.

13. Cao HX, Vu GTH, Wang W, Messing J, Schubert I. Chromatin organisation in duckweed interphase nuclei in relation to the nuclear DNA content. Plant Biol. 2015;17:120-4. https://doi.org/10.1111/plb.12194.

14. Wang W, Messing J. Status of duckweed genomics and transcriptomics. Plant Biol. 2015;17:10-5. https://doi.org/10.1111/plb.12201.

15. Anderson JL, Thomson WW, Swader JA. Fine structure of Wolffia arrhiza. Can J Bot. 1973;51(9):1619-22. https://doi.org/10.1139/b73-206.

16. Bernard FA, Bernard JM. Flower structure, anatomy and life history of Wolffia australiana (Benth.) den Hartog \& van der Plas. Bulletin of the Torrey Botanical Club. 1990;117(1):18-26. https://doi.org/10.2307/2997125.

17. White SL, Wise RR. Anatomy and ultrastructure of Wolffia columbiana and Wolffia borealis, two nonvascular aquatic angiosperms. Int J Plant Sci. 1998; 159(2):297-304. https://doi.org/10.1086/297550.

18. Lemon GD, Posluszny. Comparative shoot development and evolution in the lemnaceae. Int J Plant Sci. 2000;161(5):733-48. https://doi.org/10.1 086/314298.

19. Sree KS, Maheshwari SC, Boka K, Khurana JP, Keresztes A, Appenroth KJ. The duckweed Wolffia microscopica: a unique aquatic momocot. Flora. 2015;210: 31-9. https://doi.org/10.1016/j.flora.2014.10.006.

20. Huang Q. A comprehensive study on Wolffia globosa. Beijing: Institute of Botany, Chinese Academy of Sciences; 2007.

21. Heenatigala PPM, Yang JJ, Bishopp A, Sun ZL, Li GJ, Kumar S, et al. Development of efficient protocols for the stable and transient gene transformation for Wolffia globosa using Agrobacterium. Front Chem. 2018;6: 227. https://doi.org/10.3389/fchem.2018.00227

22. Boonyapookana B, Upatham ES, Kruatrachue $M$, Pokethitiyook $P$ Singhakaew S. Phytoaccumulation and phytotoxicity of cadmium and chromium in duckweed Wolffia globosa. Int J Phytoremediation. 2002:4(2): 87-100. https://doi.org/10.1080/15226510208500075.

23. Zhang $X$, Uroic MK, Xie WY, Zhu YG, Chen BD, McGrath SP, et al. Phytochelatins play a key role in arsenic accumulation and tolerance in the aquatic macrophyte Wolffia globosa. Environ Pollut. 2012;165:18-24.

24. Michael TP, Ernst E, Hartwick N, Chu P, Bryant D, Gilbert S, et al. Genome and time-of-day transcriptome of Wolffia australiana link morphological minimization with gene loss and less growth control. Genome Res. 2021;23: 225-38.

25. Weigel D, Jurgens G. Stem cells that make stems. Nature. 2002;415(6873): 751-4. https://doi.org/10.1038/415751a.

26. Maugarny-Cales A, Laufs P. Getting leaves into shape: a molecular, cellular, environmental and evolutionary view. Development. 2018;145:161646.

27. Zadnikova P, Simon R. How boundaries control plant development. Curr Opin Plant Biol. 2014;17:116-125w.

28. Ziegler P, Adelmann K, Zimmer S, Schmidt C, Appenroth KJ. Relative in vitro growth rates of duckweeds (Lemnaceae)-the most rapidly growing higher plants. Plant Biol. 2013;1:AN33-41.
29. Fourounjian P, Slovin J, Messing J. Flowering protocol optimization in the Lemnaceae. The $5^{\text {th }}$ ICDRA. Rehovot, Israel. 2019.

30. Khurana JP, Maheshwari SC. Floral induction in Wolffia microscopica by salicylic acid and related compounds under non-inductive long days. Plant \& Cell Physiol. 1983;24(5):907-12. https://doi.org/10.1093/oxfordjournals. pcp.a076594.

31. Cao HX, Vu GTH, Wang W, Appenroth KJ, Messing J, Schubert I. The mapbased genome sequence of Spirodela polyrhiza aligned with its chromosomes, a reference for karyotype evolution. New Phytol. 2016;209(1): 354-63. https://doi.org/10.1111/nph.13592.

32. Gorham PR. Measurement of the response of Lemna to growth promoting substances. Am J Bot. 1941;28(2):98-101. https://doi.org/10.1002/j.1537-21 97.1941.tb07948x

33. Ice J, Couch R. Nutrient absorption by duckweed. J Aquat Plant Manage. 1987;25:30-1.

34. Meijer LE, Sutton DL. Influence of plant position on growth of duckweed. J Aquat Plant Manage. 1987;25:28-30.

35. Muhonen M, Showman J, Couch R. Nutrient absorption by Spirodela polyrhiza. J Aquat Plant Manage. 1983;21:107-9.

36. Echlin $P$, Lai CE, Hayes TL. Low-temperature X-ray microanalysis of the differentiating vascular tissue in root tips of Lemna minor L. J Microsc. 1981; 126:285-306.

37. Kim IS. Development of the root system in Spirodela polyrhiza (L.) Schleiden (Lemnaceae). J Plant Biol. 2007;50(5):540-7. https://doi.org/10.1007/BF0303 0707.

38. Tippery NP, Les DH, Crawford DJ. Evalutation of phylogenetic relationships in Lemnaceae using nuclear ribosomal data. Plant Biol. 2015;17:50-8. https://doi.org/10.1111/plb.12203.

39. Cantó-Pastor A, Mollá-Morales A, Ernst E, Dahl W, Zhai J, Yan Y, et al. Efficient transformation and artificial miRNA gene silencing in Lemna minor. Plant Biol. 2015;17:59-65. https://doi.org/10.1111/plb.12215.

40. Yang JJ, Li GJ, Hu SQ, Bishopp A, Heenatigala PPM, Kumar S, et al. A protocol for efficient callus induction and stable transformation of Spirodela polyrhiza (L.) Schleiden using Agrobacterium tumefaciens. Aquat Bot. 2018b; 151:80-6. https://doi.org/10.1016/j.aquabot.2018.08.004

41. Hillman WS. The Lemnaceae, or duckweeds: a review of the descriptive and experimental literature. Bot Rev. 1961;27(2):221-87. https://doi.org/10.1007/ BF02860083.

42. Schenk RU, Hildebrandt AC. Medium and techniques for induction and growth of monocotyledonous and dicotyledonous plant cell cultures. Can J Bot. 1972;50(1):199-204. https://doi.org/10.1139/b72-026.

43. Wang W, Wu Y, Yan Y, Ermakova M, Kerstetter R, Messing J. DNA barcoding of the Lemnaceae, a family of aquatic monocots. BMC Plant Biol. 2010;10(1): 205. https://doi.org/10.1186/1471-2229-10-205.

\section{Publisher's Note}

Springer Nature remains neutral with regard to jurisdictional claims in published maps and institutional affiliations.
Ready to submit your research? Choose BMC and benefit from:

- fast, convenient online submission

- thorough peer review by experienced researchers in your field

- rapid publication on acceptance

- support for research data, including large and complex data types

- gold Open Access which fosters wider collaboration and increased citations

- maximum visibility for your research: over $100 \mathrm{M}$ website views per year

At $\mathrm{BMC}$, research is always in progress.

Learn more biomedcentral.com/submissions 